\title{
PROFIL KEMAMPUAN PEMECAHAN MASALAH MATEMATIKA SISWA DITINJAU DARI GAYA KOGNITIF REFLEKTIF
}

\author{
Sefna Rismen ${ }^{1}$, Ratulani Juwita ${ }^{2}$, Uchy Devinda ${ }^{3}$ \\ 1,2,3 Program Studi Pendidikan Matematika, STKIP PGRI Sumatera Barat \\ syefna@gmail.com
}

\begin{abstract}
Research is motivated by the low ability of students to solve mathematical problems and differences in the characteristics of students in receiving and organizing and processing information in solving problems. The research aims to find out how students' mathematical problem solving abilities are viewed from the reflective cognitive style. This type of research is a descriptive study with a qualitative approach with research subjects, namely 3 students with abilities (high, medium and low) in the XII grade of Mathematics and Natural Sciences 3 of SMAN 1 Batang Anai, Padang Pariaman Regency. The research instrument was in the form of a Matching Familiar Figure Test (MFFT) test, a problem solving and interview ability test. Data analysis techniques in this study used qualitative data analysis techniques, namely data reduction, data presentation and drawing conclusions. The results of this study indicate that the mathematical problem solving ability of students who have a more dominant reflective cognitive style has the ability to solve mathematical problems in the medium criteria.
\end{abstract}

\section{Keywords: Problem Solving Ability, Cognitive Style, Reflective Cognitive Style.}

\begin{abstract}
Abstrak
Penelitian dilatar belakangi oleh rendahnya kemampuan pemecahan masalah matematika siswa dan perbedaan karakteristik siswa dalam menerima dan mengorganisasikan serta mengolah informasi dalam menyelesaikan masalah. Penelitian bertujuan untuk mengetahui bagaimana kemampuan pemecahan masalah matematika siswa ditinjau dari gaya kognitif reflektif. Jenis penelitian adalah penelitian deskriptif dengan pendekatan kualitatif dengan subjek penelitian yaitu 3 orang siswa dengan kemampuan (tinggi, sedang dan rendah) pada kelas XII MIPA 3 SMAN 1 Batang Anai Kabupaten Padang Pariaman. Instrumen penelitian berbentuk sebuah tes Matching Familiar Figure Test (MFFT), tes kemampuan pemecahan masalah dan wawancara. Teknik analisis data pada penelitian ini menggunakan teknik analisis data kualitatif yaitu reduksi data, penyajian data dan penarikan kesimpulan. Hasil penelitian ini menunjukkan bahwa kemampuan pemecahan masalah matematika siswa yang memiliki gaya kognitif reflektif lebih dominan memiliki kemampuan pemecahan masalah matematika pada kriteria sedang.
\end{abstract}

Kata kunci: Kemampuan Pemecahan Masalah, Gaya Kognitif, Gaya Kognititf Reflektif

\section{PENDAHULUAN}

Menurut Kemendikbud No. 59 (2014: 325) matematika merupakan ilmu universal yang berguna bagi kehidupan manusia serta mempunyai peran penting dalam berbagai disiplin dan memajukan daya pikir manusia. Matematika perlu diberikan kepada semua siswa mulai dari sekolah dasar, untuk membekali siswa dengan kemampuan berpikir logis, analitis, sistematis, kritis, inovatif dan kreatif, serta kemampuan bekerja sama. Namun menurut (Dewi, Khodijah, \& Zanthy, 2020) pada kenyataannya matematika masih dianggap sebagai mata pelajaran yang sulit untuk dipelajari. Dari kutipan diatas, mengingat matematika adalah salah satu ilmu yang memiliki peran penting, maka diharapkan siswa harus dapat merasakan kegunaan dalam belajar matematika. Salah satu tujuan pembelajaran matematika yang harus dikuasai oleh siswa adalah kemampuan pemecahan masalah.

Pemecahan masalah adalah suatu hal yang sangat penting dalam belajar matematika. Hal ini 
sejalan dengan pendapat (Akbar, Hamid, Bernard, \& Sugandi, 2017) hampir setiap Standar kompetensi dan Kompetensi Dasar dijumpai penegasan diperlukannya kemampuan pemecahan masalah. Pada dasarnya kemampuan pemecahan masalah merupakan satu kemampuan matematika yang penting dan perlu dikuasai oleh siswa yang belajar matematika, rasional yang mendasari kebenaran pernyataan tersebut diantaranya adalah : a) KTSP Matematika 2006 (Hendriana, Rohaeti, Soemarmo, 2017) mengemukakan Pemecahan masalah matematik merupakan kemampuan yang tercantum dalam kurikulum dan tujuan pembelajaran matematika; b) Bahkan, Branca (Hendriana, Rohaeti, Soemarmo, 2017) mengemukakan bahwa pemecahan masalah matematika meliputi metode, prosedur dan strategi yang merupakan proses inti dan utama kurikulum matematika atau merupakan tujuan umum pembelajaran matematika, bahkan sebagai jantungnya matematika.

Pemecahan masalah matematika merupakan proses menerapkan pengetahuan yang telah diperoleh sebelumnya kedalam bentuk situasi baru yang belum dikenal. Untuk menjadi seorang pemecahan masalah yang baik, siswa membutuhkan banyak kesempatan dan memecahkan masalah dalam bidang matematika dan dalam konteks kehidupan nyata (Silva, Zulkardi, \& Darmawijoyo, 2011), sejalan dengan pendapat (Puspita, 2016) memecahkan masalah akan mengembangkan kemampuan untuk membangun ide-ide dan dapat berlatih mengintegrasikan konsep-konsep, teorema-teorema, dan keterampilan yang telah dipelajari, sehingga pemecahan masalah sangat penting dalam pembelajaran matematika. Menurut Polya dalam (Ariani, Hartono, \& Hiltrimartin, 2017) untuk memecahkan masalah ada empat langkah yang dapat dilakukan yaitu memahami masalah, menyusun rencana penyelesaian, menyelesaikan rencana penyelesaian, dan memeriksa kembali.

Hasil penelitian yang dilakukan oleh (Purnamasari, 2015) pada siswa kelas XI SMK Muhammadiyah 1 Patuk menunjukkan bahwa siswa yang memiliki kemampuan pemecahan masalah pada kualifikasi yang tinggi hanya $11,77 \%$, dan siswa yang memiliki kemampuan pemecahan masalah rendah dan sangat rendah sebanyak 52,94\%. Siswa mengalami kesulitan dalam memecahkan masalah yang disebabkan oleh beberapa hal diantaranya siswa kurang memahami masalah yang diberikan. sehingga mengakibatkan tahap-tahap selanjutnya seperti menyusun rencana penyelesaian, menyelesaikan masalah, dan memeriksa kembali menjadi kurang tepat. Dari hasil penelitian di atas terlihat lebih dari 50\% siswa memiliki kemampuan pemecahan masalah tergolong dalam kategori rendah.

Hasil observasi yang dilakukan di SMAN 1 Batang Anai Kabupaten Padang Pariaman, pada proses pembelajaran matematika terlihat bahwa siswa mampu menyelesaikan soal latihan dengan bentuk yang sama dengan yang dicontohkan oleh guru, akan tetapi ketika guru memberikan bentuk soal latian yang berbeda dengan yang dicontohkan guru, siswa terlihat kebingungan untuk menyelesaikan soal tersebut, karena siswa terbiasa dengan cara yang dijelaskan oleh guru. Sehingga siswa tidak terbiasa untuk menyelesaikan soal non rutin yang mengakibatkan kemampuan pemecahan masalah matematika tidak terjadi peningkatan. 
Rendahnya kemampuan pemecahan masalah matematika diatas dapat dipengaruhi oleh beberapa faktor. Menurut (Ulya, 2015) faktor tersebut muncul karena setiap individu memliki perbedaan pada saat memecahkan masalah salah satu faktor yang mempengaruhi kemampuan pemecahan masalah adalah gaya kognitif. Gaya kognitif adalah kecenderungan individu untuk memahami, berpikir, dan menyimpan informasi (Hadfield \& Maddux, 1988) dalam (Setiawan, Purwanto, Parta, \& Sisworo, 2020). Menurut Desmita (2010:147) salah satu gaya kognitif tersebut adalah gaya kognitif reflektif dan impulsif.

Gaya kognitif reflektif dan impulsif merupakan gaya kognitif yang menunjukkan konseptual tempo atau kecepatan dalam berpikir. Tempo atau kecepatan yang dimaksud adalah waktu yang digunakan untuk merespons suatu informasi yang diterima. Siswa yang memiliki karakteristik lambat dalam menyelesaikan masalah, tetapi cermat / teliti, sehingga jawaban cenderung benar, disebut dengan siswa bergaya kognitif reflektif (Warli, 2013).

Gaya kognitif, khususnya gaya kognitif reflektif dan impulsif mempunyai kontribusi yang penting dalam memecahkan masalah, hal ini memungkin bahwa siswa dengan gaya kognitif berbeda akan mempunyai pemecahan masalah yang berbeda pula (Puspita, 2016). Dapat dilihat dari hasil penelitiannya pada kelas VIII-C SMP Negeri 36 Surabaya disimpulkan bahwa siswa dengan gaya kognitif reflektif mampu menyelesaikan semua soal yang diberikan dan bisa mencapai setiap tahap pemecahan masalah Polya dengan benar.

Berdasarkan penelitian diatas, maka disimpulkan ada terdapat keterkaitan pemecahan masalah matematika siswa dengan gaya kognitif reflektif yang dimiliki siswa dalam proses pembelajaran matematika. Tujuan penelitian ini untuk mengetahui bagaimana kemampuan pemecahan masalah matematika ditijau dari gaya kognitif reflektif siswa kelas XII MIPA 3 SMAN 1 Batang Anai Kabupaten Padang Pariaman.

\section{METODE}

Untuk mengetahui kemampuan pemecahan masalah matematika yang dimiliki siswa ditinjau dari gaya kognitif reflektif sebagaimana tujuan dari penelitian, maka jenis penelitian yang digunakan adalah penelitian deskriptif dengan pendekatan kualitatif. Subjek penelitian merupakan tiga orang siswa pada kelas XII MIPA 3 SMAN 1 Batang Anai Kabupaten Padang Pariaman yang terdaftar pada semester ganjil tahun ajaran 2019/2020. Pemilihan subjek pada penelitian ini menggunakan pertimbangan tertentu, yaitu: 1) Kriteria kemampuan pemecahan masalah yang diperoleh siswa, 2) Kelompok reflektif diambil dari siswa yang memiliki waktu paling lama dan cermat/akurat dalam menjawab (frekuensi salah sedikit), dan 3) memiliki komunikasi yang baik secara lisan dan tertulis.

Instrumen penelitian meliputi instrumen tes Familiar Figures Test (MFFT), tes Kemampuan Pemecahan Masalah Matematika (KPM), dan wawancara. Tes MFFT digunakan untuk mengelompokkan siswa berdasarkan gaya kognitif reflektif dan impulsif. Tes MFFT ini diadobsi dari 
tes MFFT yang dimodifikasi oleh warli dalam (Vahrum \& Rahaju, 2016). MFFT ini terdiri dari 15 soal, 2 buah soal sebagai soal percobaan dan 13 soal sebagai soal tes, setiap soal berbentuk gambar, yang terdiri dati 2 macam gambar, yang pertama gambar standar (baku) sebayak 1 gambar dan gambar variasi (stimulus) sebanyak 8 gambar. Tes kemampuan pemecahan masalah matematika terdiri dari 3 buah soal uraian yang disusun oleh peneliti berupa soal materi geometri ruang yang merupaka soal pemecahan masalah yang sudah divalidasi oleh 4 orang validator dan dilakukan uji coba soal untuk melihat soal dapat digunakan sebagai alat pengumpulan data. Wawancara terdiri dari beberapa pertanyaanpertanyaan yang diajukan berdasarkan langkah-langkah kemampuan pemecahan masalah dari tes kemampuan pemecahan masalah yang telah dilakukan oleh subjek.

Teknik analisis pada penelitian ini mengguakan teknik analisis data kualitatif menurut Miles dan Huberman dalam Sugiyono (2017:132) yaitu reduksi data, penyajian data dan penarikan kesimpulan sebagai berikut:

\section{Reduksi Data}

Tahap reduksi pada penelitian ini diperoleh dari hasil analisis tes MFFT, tes KPM dan wawancara. Analisis tes MFFT menggunakan penetapan yang dilakukan oleh Warli dalam (Vahrum \& Rahaju, 2016). Siswa dikatakan memiliki gaya kognitif reflective jika menyelesaikan MFFT dalam waktu $>$ 7,28 menit dan memiliki jawaban salah $<7$ soal. Data yang diperoleh dari tes MFFT dicatat meliputi banyak waktu yang digunakan siswa saat menyelesaikan tes (t) dan banyaknya kesalahan siswa dalam mengerjakan tes (f). Selanjutnya analisis tes KPM menggunakan rubrik penskoran pemecahan masalah berdasarkan langkah-langkah pemecahan masalah menurut Polya sebagai berikut:

\section{Tabel 1.}

Indikator Penskoran kemampuan Pemecahan Masalah

\begin{tabular}{|c|c|c|}
\hline $\begin{array}{l}\text { Aspek Yang } \\
\text { Dinilai }\end{array}$ & Reaksi Terhadap Soal & Skala \\
\hline \multirow{4}{*}{$\begin{array}{l}\text { Memahami } \\
\text { masalah }\end{array}$} & Tidak ada jawaban sama sekali. & 0 \\
\hline & $\begin{array}{l}\text { Menuliskan diketahui/ditanyakan/sketsa/model tetapi salah atau tidak } \\
\text { memahami masalah sama sekali. }\end{array}$ & 1 \\
\hline & Memahami informasi atau permasalahan dengan kurang tepat/lengkap. & 2 \\
\hline & Berhasil memahami masalah secara menyeluruh. & 3 \\
\hline \multirow{4}{*}{$\begin{array}{l}\text { Menyusun } \\
\text { rencana } \\
\text { penyelesaian }\end{array}$} & Tidak ada urutan langkah penyelesaian sama sekali. & 0 \\
\hline & $\begin{array}{l}\text { Strategi/langkah penyelesaian ada tetapi tidak relevan atau tidak/belum } \\
\text { jelas. }\end{array}$ & 1 \\
\hline & $\begin{array}{l}\text { Strategi/langkah penyelesaian mengarah pada jawaban yang benar tetapi } \\
\text { tidak lengkap atau jawaban salah. }\end{array}$ & 2 \\
\hline & Menyajikan langkah penyelesaian yang benar. & 3 \\
\hline \multirow{3}{*}{$\begin{array}{l}\text { Menyelesaik } \\
\text { an rencana } \\
\text { penyelesaian }\end{array}$} & Tidak ada penyelesaian sama sekali. & 0 \\
\hline & Ada penyelesaian, tetapi prosedure tidak jelas/salah. & 1 \\
\hline & $\begin{array}{l}\text { Menggunakan prosedur tertentu yang benar tetapi perhitungan } \\
\text { salah/kurang lengkap. }\end{array}$ & 2 \\
\hline
\end{tabular}


Profil Kemampuan Pemecahan Masalah Matematika Siswa Ditinjau Dari Gaya Kognitif Reflektif, Sefna Rismen, Ratulani Juwita, Uchy Devinda

\begin{tabular}{|c|l|c|}
\hline & Menggunakan prosedure tertentu yang benar. & 3 \\
\hline \multirow{2}{*}{$\begin{array}{c}\text { Memeriksa } \\
\text { kembali } \\
\text { terhadap proses juga hasil jawaban. }\end{array}$} & $\begin{array}{l}\text { Jika menuliskan kesimpulan dan/atau melakukan pengecekan terhadap } \\
\text { proses dengan kurang tepat. } \\
\text { Atau melakukan pengecekan } \\
\text { Jika hanya menuliskan kesimpulan saja atau melakukan pengecekan } \\
\text { terhadap proses saja dengan tepat. }\end{array}$ & 1 \\
\cline { 2 - 3 } & $\begin{array}{l}\text { Jika menuliskan kesimpulan dan melakukan pengecekan terhadap proses } \\
\text { dengan tepat. }\end{array}$ & 2 \\
\hline
\end{tabular}

Sumber: Polya dalam (Ariani et al., 2017)

Kemudian jumlah skor yang diperoleh selanjutnya dirubah kedalam skala angka (0-100), maka untuk menentukan kriteria yang dimiliki siswa dapat dilihat sebagai berikut:

\section{Tabel 2.}

Kriteria Kemampuan Pemecahan Masalah Matematika

\begin{tabular}{|c|c|}
\hline Kriteria & Nilai \\
\hline Sangat Tinggi & $81 \leq \mathrm{N} \leq 100$ \\
\hline Tinggi & $61 \leq \mathrm{N} \leq 80$ \\
\hline Sedang & $41 \leq \mathrm{N} \leq 60$ \\
\hline Rendah & $21 \leq \mathrm{N} \leq 40$ \\
\hline Sangat Rendah & $0 \leq \mathrm{N} \leq 20$ \\
\hline
\end{tabular}

Sumber: Modifikasi dari (Hidayat \& Irawan, 2017)

Keterangan: $\mathrm{N}$ adalah nilai kemampuan pemecahan masalah siswa

Sedangkan untuk hasil wawancara dituangkan dalam bentuk tertulis dengan langkah-langkah sebagai berikut: 1) Mendengarkan hasil rekaman wawancara sehingga dapat menuliskan dengan benar apa yang diucapkan oleh subjek, 2) Membuat transkrip hasil wawancara yang telah didengarkan dan 3) Memeriksa kembali transkrip hasil wawancara dengan cara mendengarkan kembali rekaman wawancara.

\section{Peyajian Data}

Pada penelitian ini, setelah dilakukan reduksi data, maka data tes MFFT dan tes KPM disajikan dalam bentuk tabel dan diurutkan sesuai dengan penetapan yang telah di tentukan. Sedangkan data wawancara disajikan dalam bentuk kode-kode percakapan antara peneliti dengan subjek agar dapat memahami hasil wawancara dengan mudah.

\section{Kesimpulan}

Penarikan kesimpulan diambil berdasarkan data yang telah dianalisis, meliputi tes MFFT, tes KPM dan hasil wawancara dengan tujuan memperoleh kesimpulan tentang kemampuan pemecahan masalah matematika ditinjau dari gaya kognitif reflektif siswa kelas XII MIPA 3 SMAN 1 Batang Anai Kabupaten Padang Pariaman. 


\section{HASIL}

Pengelompokan gaya kognitif menggunakan tes MFFT yang dilakukan pada kelas XII MIPA 3 berdasarkan penetapan Warli diperoleh bahwa siswa lebih umum memiliki gaya kognitif reflektif. Selanjutnya, dilakukan tes kemampuan pemecahan masalah kepada seluruh siswa, hasil yang diperoleh bahwa siswa lebih dominan memiliki kemampuan pemecahan masalah matematika pada kriteria sedang. Setelah dilakukannya tes MFFT dan tes KPM maka diperoleh hasil sebagai berikut:

\section{Tabel 3.}

Data Hasil Tes Pengelompokan Kemampuan Pemecahan Masalah Matematika Ditinjau Dari Gaya Kognitif Reflektif

\begin{tabular}{|c|l|l|c|c|c|c|}
\hline \multirow{2}{*}{ No } & \multirow{2}{*}{ Nama } & \multicolumn{3}{|c|}{ Tes MFFT } & \multirow{2}{*}{ KPM } & \multirow{2}{*}{ Nilai } \\
\cline { 3 - 6 } & & $\boldsymbol{F}$ & $\boldsymbol{r}$ & $\boldsymbol{t}$ & & \\
\hline 1 & MV & 6 & 7 & $12: 12$ & Tinggi & 79 \\
\hline 2 & SWP & 4 & 9 & $12: 01$ & Sedang & 60 \\
\hline 3 & DSP & 6 & 7 & $13: 06$ & Sedang & 55 \\
\hline 4 & SM & 4 & 9 & $16: 14$ & Sedang & 55 \\
\hline 5 & NN & 6 & 7 & $10: 33$ & Sedang & 52 \\
\hline 6 & NP & 5 & 8 & $14: 08$ & Sedang & 50 \\
\hline 7 & RF & 6 & 7 & $13: 32$ & Sedang & 48 \\
\hline 8 & HF & 5 & 8 & $9: 38$ & Sedang & 45 \\
\hline 9 & MS & 8 & 5 & $8: 10$ & Sedang & 43 \\
\hline 10 & MD & 4 & 9 & $12: 29$ & Rendah & 40 \\
\hline 11 & A & 5 & 8 & $12: 54$ & Rendah & 38 \\
\hline 12 & F & 6 & 7 & $13: 34$ & Rendah & 33 \\
\hline 13 & YA & 4 & 9 & $15: 23$ & Rendah & 33 \\
\hline 14 & VMH & 4 & 9 & $16: 14$ & Rendah & 29 \\
\hline 15 & YS & 5 & 8 & $16: 16$ & Rendah & 29 \\
\hline 16 & FIYS & 6 & 7 & $20: 59$ & Rendah & 24 \\
\hline
\end{tabular}

Keterangan :

$f:$ Jumlah jawaban yang salah

$r$ : Jumlah jawaban benar

$t$ : Waktu pengerjaan

Tabel 3. menunjukkan siswa dengan gaya kognitif reflektif memiliki kemampuan pemecahan masalah matematika siswa berada pada kriteria tinggi sebanyak 1 orang atau 6,25\%, sedang sebanyak 8 orang atau $50 \%$, dan rendah sebanyak 7 orang atau $43,75 \%$. Dilihat dari persentase maka kemampuan pemecahan masalah matematis siswa yang memiliki gaya kognitif reflektif tertinggi berada pada 
kriteria sedang. Untuk mendeskripsikan kemampuan pemecahan masalah ditijau dari gaya kognitif reflektif dipilih satu siswa dengan kemampuan pemecahan masalah yang berbeda.

Subjek yang dipilih untuk mewakili siswa dengan kemampuan pemcahan masalah tinggi adalah siswa MV, untuk siswa yang mewakili kemampuan pemecahan masalah sedang diwakili oleh siswa SM, dan YA mewakili siswa dengan kemampuan pemecahan masalah rendah. Maka kemampuan pemecahan masalah matematika ditinjau berdasarkan gaya kognitif reflektif dapat dilihat sebagai berikut:

\section{Kemampuan Pemecahan Masalah Pada Kriteria Tinggi}

Berdasarkan tahap pemecahan masalah Polya, siswa yang memiliki kemampuan pemecahan masalah tinggi sudah mengerjakan semua indikator langkah kemampuan pemecahan masalah menurut Polya. Siswa MV mengerjakan semua soal yang diberikan yaitu sebanyak 3 soal. Pada tahap memahami masalah siswa sudah mampu untuk menuliskan apa yang diketahui dan apa yang ditanya dari ke tiga soal yang diberikan. Untuk soal nomor 1 dan 2 siswa sudah sangat baik dalam memahami masalah akan tetapi pada soal nomor 3 siswa kurang tepat dalam memahami masalah yang diberikan, berdasarkan wawancara yang dilakukan untuk memahmi masalah siswa membaca soal sebanyak 2 kali. Siswa sudah mampu menyusun rencana penyelesaian pada semua soal, tetapi rencana penyelesaian yang dilakukan pada soal nomor 1 dan 3 kurang tepat sedangkan untuk soal nomor 2 siswa sudah menyusun rencana penyelesaian dengan tepat. Pada tahap melaksanakan rencana penyelesaian untuk soal nomor 1 dan 2 siswa sudah menyelesaikan rencana penyelesaian dengan benar, sedangkan pada soal nomor 3 siswa sudah menyelesaikan rencana penyelesaian, tetapi penyelesaian yang dilakukan salah dikarenakan siswa kurang tepat pada saat memahami masalah dan mengakibatkan hasil yang diperoleh menjadi salah. Pada tahap memeriksa kembali untuk ketiga soal siswa sudah menuliskan sebuah kesimpulan dan berdasarkan wawancara siswa melakukan pemeriksaan kembali pada penyelesaian yang telah dikerjakan.

\section{Kemampuan Pemecahan Masalah Pada Kriteria Sedang}

Berdasarkan tahap pemecahan masalah Polya, siswa yang memiliki kemampuan pemecahan masalah pada kriteria sedang belum menuliskan semua indikator langkah kemampuan pemecahan masalah menurut Polya. Siswa SM sudah mengerjkan semua soal, yaitu sebanyak 3 soal. Pada tahap memahami masalah siswa sudah menuliskan apa yang diketahui dan apa yang ditanyakan soal dengan sangat baik, akan tetapi untuk soal nomor 3 siswa kurang tepat dalam memahami soal yang diberikan, SM mengatakan agar mehami masalah yang diberikan siswa membaca soal nomor 1 dan 2 sebanyak dua kali dan untuk soal nomor 3 membaca sebanyak tiga kali. Pada tahap menyusun rencana penyelesaian pada soal nomor 1 dan 3 siswa kurang tepat, akan tetapi untuk soal nomor 2 siswa sudah tepat dalam menyusun rencana penyelesaian yang akan dilakukan. Pada tahap melaksanakan rencana penyelesaian untuk soal nomor 1 dan 3 siswa sudah membuat penyelesaiaan, tetapi penyelesaian yang dilakukan siswa salah, sedangkan untuk soal nomor 2 siswa sudah melaksanakan rencana penyelesaian dengan benar. Selanjutnya, Siswa belum menuliskan sebuah kesimpulan dari penyelesaian yang 
dilakukan, tetapi pada wawancara siswa mengatakan ada memeriksa pekerjaan yang dilakukan, maka dapat disimpulkan siswa kurang tepat dalam langkah memeriksa kembali.

\section{Kemampuan Pemecahan Masalah Pada Kriteria Rendah}

Berdasarkan tahap pemecahan masalah Polya, siswa yang memiliki kemampuan pemecahan masalah pada kriteria rendah belum menuliskan semua indikator langkah kemampuan pemecahan masalah menurut Polya. Siswa dengan kemampuan pemecahan masalah rendah mengerjakan 2 soal dari 3 soal yang diberikan. Pada tahap memahami masalah untuk soal nomor 1 dan dua siswa sudah menuliskan apa yang diketahui dan apa yang ditanya pada soal dan siswa sudah memahami masalah sebelum membuat sebuah perencanaan dengan baik. Pada tahap menyu sun rencana penyelesaian untuk soal nomor 1 siswa sudah membuat rencana penyelesaian tetapi penyelesaian yang dilakukan belum tepat, sedangkan untuk soal nomor 2 siswa sudah menyusun rencana penyelesaian dengan tepat. Pada tahap menyelesaikan rencana penyelesaian untuk soal nomor 1 siswa sudah melaksanakan rencana penyelesaian, tetapi penyelesaian yang dilakukan salah, sedangkan untuk soal nomor 2 siswa sudah melaksanakan penyelesaian tetapi penyelesaian yang dilakukan kurang tepat diakibatkan siswa kurang tepat dalam perhitungan yang dilakukan. Pada tahap memeriksa kembali untuk soal nomor 1 dan 2 siswa belum menuliskan kesimpulan dari penyelesaian yang dilakukan, tetapi siswa mengatakan pada wawancara yang telah dilakukan siswa ada memeriksa pekerjaan yang dilakukan untuk soal nomor 1 tetapi tidak ada memeriksa kembali untuk soal nomor 2.

\section{KESIMPULAN}

Berdasarkan hasil analisis data dan pembahasan yang telah dilakukan maka dapat disimpulkan bahwa kemampuan pemecahan masalah matematika siswa yang memiliki gaya kognitif reflektif kelas XII MIPA 3 SMAN 1 Batang Anai Kabupaten Padang Pariaman kualifikasi tinggi 6,25 \%, sedang 50 $\%$ dan rendah $43,75 \%$, Jadi dapat disimpulkan, kemampuan pemecahan masalah matematis siswa yang memiliki gaya kognitif reflektif lebih dominan berada pada kriteria sedang. Artinya siswa dalam melakukan penyelesaian masalah belum memahami semua masalah yang diberikan secara baik, sehingga penyusunan perencanaan peyelesaian masalah juga kurang tepat, kemudian siswa juga banyak melakukan kesalahan dalam perhitungan, dan tidak menarik kesimpulan dari jawaban soal yang dikerjakan.

\section{DAFTAR PUSTAKA}

Akbar, P., Hamid, A., Bernard, M., \& Sugandi, A. I. (2017). Analisis Kemampuan Pemecahan Masalah Dan Disposisi Matematik Siswa Kelas Xi Sma Putra Juang Dalam Materi Peluang. Jurnal Cendekia: Jurnal Pendidikan Matematika, 2(1), 144-153. https://doi.org/10.31004/cendekia.v2i1.62

Ariani, S., Hartono, Y., \& Hiltrimartin, C. (2017). Kemampuan Pemecahan Masalah Matematika Siswa pada Pembelajaran Matematika Menggunakan Strategi Abduktif-Deduktif di SMA Negeri 1 
Profil Kemampuan Pemecahan Masalah Matematika Siswa Ditinjau Dari Gaya Kognitif Reflektif, Sefna Rismen, Ratulani Juwita, Uchy Devinda

Indralaya Utara. Jurnal Elemen, 3(1), 25. https://doi.org/10.29408/jel.v3i1.304

Desmita. (2010).Psikologi Perkembangan Peserta Dididk. Bandung: PT remaja Rosdakarya.

Dewi, D. K., Khodijah, S. S., \& Zanthy, L. S. (2020). Analisis kesulitan matematik siswa smp pada materi statistika. Jurnal Cendekia : Jurnal Pendidikan Matematika, 4(1), 1-7.

Hidayat, A., \& Irawan, I. (2017). Pengembangan Lks Berbasis Rme Dengan Pendekatan Problem Solving Untuk Memfasilitasi Kemampuan Pemecahan Masalah Matematis Siswa. Jurnal Cendekia: Jurnal Pendidikan Matematika, 1(2), 51-63. https://doi.org/10.31004/cendekia.v1i2.20.

Kemendikbud. (2014). Kurikulum SMA/MA. Jakarta: Kemendikbud

Purnamasari, P. D. (2015). Analisis Kemampuan Pemecahan Masalah Matematika Siswa Kelas XI SMK MUHAMMADIYAH I Patuk Pada Pokok Bahasan Peluang.

Puspita, A. Y. A. (2016). Profil Pemecahan Masalah Matematika Siswa Pada Materi Segiempat Ditinjau Dari Gaya Kognitif Relektif Dan Implusif. Ilmiah Pendidikan Matematika, 3(5).

Setiawan, Y. E., Purwanto, Parta, I. N., \& Sisworo. (2020). Generalization strategy of linear patterns from field-dependent cognitive style. Journal on Mathematics Education, 11(1), 77-94. https://doi.org/10.22342/jme.11.1.9134.77-94

Silva, E. Y., Zulkardi, \& Darmawijoyo. (2011). Pengembangan Soal Matematika Model Pisa Pada Konten Uncertainty Untuk Mengukur Kemampuan Pemecahan Masalah Matematika Siswa Sekolah Menengah Pertama. Jurnal Pendidikan Matematika, 5(vol 5, No 1 (2011)).

Ulya, H. (2015). Hubungan Gaya Kognitif Dengan Kemampuan Pemecahan Masalah Mmatematika Siswa. Konseling GUSJIGANG, 1(2).

Vahrum, F. N., \& Rahaju, E. B. (2016). Proses Berpikir Siswa SMP Dalam Memecahkan Masalah Matematika Kontekstual Pada Materi Himpunan Berdasarkan Gaya Kognitif Impulsive Dan Reflektive. 3(5).

Warli. (2013). Kreativitas Siswa SMP Yang Bergaya Kognitif Reflektif Atau Impulsif Dalam Memecahkan Masalah Geometri. Jurnal Pendidikan Dan Pembelajaran Universitas Negeri Malang, 20(2), 190-201. 